Errata

\title{
Erratum to: "Genesis of chromitites from Korydallos, Pindos Ophiolite Complex, Greece, based on spinel chemistry and PGE- mineralogy", Journal of Geosciences 58: 49-69
}

\author{
Argyrios N. KAPSIOTIS \\ Leoforos Salaminas 194, Salamina, 18900, Greece; kapsiotisa@yahoo.gr \\ Received: 4 June 2013; accepted: 19 June 2013; handling editor: V. Janoušek
}

The article by Kapsiotis (2013) contains several previously published analyses (Kapsiotis et al. 2009, 2010). These data, however, have not been quoted adequately in the Journal of Geosciences paper. The previously published analyses are in Tab. 3 (p. 54), analyses G-5 and G-6 (in Tab. 4, p. 55), G-14 and G-18 (in Tab. 5, p. 56), and G-7, G-12, G-22 and G-31 (all in Tab. 6, p. 57).

Moreover, the current corresponding address of the author is identical with that of the present contribution.

\section{References}

Kapsiotis AN (2013) Genesis of chromitites from Korydallos, Pindos Ophiolite Complex, Greece, based on spinel chemistry and PGE-mineralogy. J Geosci 58: 49-69

Kapsiotis AN, Grammatikopoulos TA, Tsikouras B, Hatzipanagiotou K (2009) Platinum-Group Mineral Characterization in Concentrates from High-Grade PGE Al-rich Chromitites of Korydallos Area in the Pindos Ophiolite Complex (NW Greece). SGS Minerals Technical Bulletin 2009-10, pp 1-12

Kapsiotis AN, Grammatikopoulos TA, Tsikouras B, Hatzipanagiotou K (2010) Platinum-group mineral characterization in concentrates from high-grade PGE Al-rich chromitites of Korydallos area in the Pindos Ophiolite Complex (NW Greece). Resour Geol 60: 178-191 